\title{
ANALISIS PENGARUH PENGGUNAAN INSTAGRAM, PENGALAMAN PRAKTIK KEWIRAUSAHAAN, DAN HASIL BELAJAR KEWIRAUSAHAAN TERHADAP MINAT BERWIRAUSAHA ONLINE
}

\author{
Ignatius Soni Kurniawan \\ Universitas Sarjanawiyata Tamansiswa, Jl. Kusumanegara No. 157 Yogyakarta \\ email: soni_kurniawan@ustjogja.ac.id
}

\begin{abstract}
This research is aimed to examine the effect of instagram use, online entrepreneurial practice experience, and online entrepreneurial learning outcome on online entrepreneurial intention. A number of 84 students of Management Department, Economic Faculty of Universitas Sarjanawiyata Tamansiswa were asked to fill in the questionnaire. This study findings show that the use of instagram is not significantly affect online entrepreneurial intention, on the other way partially online entrepreneurial practice experience and online entrepreneurial learning outcomes are significantly affect online entrepreneurial intention.
\end{abstract}

Keywords: Instagram use, online entrepreneurial practice experience, online entrepreneurial learning outcome, online entrepreneurial intention.

\section{Pendahuluan}

Berbagai label diciptakan untuk menggambarkan inovasi internet saat ini, seperti era sosio ekonomi baru, era digital, revolusi industri keempat, adapun istilah revolusi industri keempat diusulkan oleh Forum Ekonomi Dunia untuk merujuk cepatnya pengembangan teknologi secara drastis dan dampaknya pada masyarakat luas (Lee, et al., 2018). Studi Google Temasek (2016) menyatakan estimasi di tahun 2025, Indonesia dan negara di Asia Tenggara, akan mencapai pendapatan USD 200 miliar dari ekonomi digital.

Kemajuan teknologi informasi menghadirkan kesempatan untuk berkomunikasi lebih luas, maka munculnya media sosial seperti Facebook, Twitter, dan Instagram menjadi hal yang fenomenal. Indonesia memiliki pengguna Facebook, Twitter, dan WhatsApp Aktif yang besar, lebih lanjut Indonesia memiliki penduduk pengguna Instagram aktif terbesar di Asia Tenggara (Statista Q4 2016 dalam Azali, 2017). Kegiatan ekonomi telah banyak ditopang oleh internet, termasuk diantaranya bidang kewirausahaan. Toko-toko telah berpindah dari brick ke click, dan efisiensi serta efektivitas pemasaran meningkat mengalahkan toko konvensional. Aplikasi perdagangan internet yang muncul secara substansial mengurangi biaya pembuatan dan pengoperasian bisnis (Millman, Wong, Li, dan Matlay, 2009). Sosial media telah dimanfaatkan sedemikan rupa untuk mendorong pemasaran secara murah dengan menargetkan jumlah pelanggan yang tak terbatas. Strategi viral marketing telah mengangkat merek global seperti Starbucks dan Apple, demikian juga Keripik Maicih di Indonesia.

Seiring meningkatnya penggunaan media internet dalam pemasaran, usaha kecil mikro pun banyak dirintis melalui blog, Kaskus, online shop (OLX, Bukalapak, Tokopedia) dan media sosial seperti Facebook, Twitter, dan Instagram. Kemudahan dan biaya murah menjadi kekuatan untuk menjangkau target pasar. Instagram juga telah 
membantu meningkatkan penjualan, meningkatkan opini konsumen terhadap merek dan kesetiaan merek (Lee \& Workman, 2015).

Pemasaran melalui media sosial virtual merupakan peluang bagi wirausahawan yang memiliki modal terbatas untuk mengkomunikasikan produknya kepada komunitas jaringan pertemanannya. Terus meningkatnya pengguna internet dan media sosial dari tahun ke tahun juga menjadi daya tarik pertumbuhan dalam proyeksi kedepan. Demikian juga pemanfaatan peluang dengan menanamkan minat berwirausaha online pada mahasiswa merupakan hal strategis untuk dilakukan sebagai bagian untuk menciptakan wirausahawan di kalangan mahasiswa. Terkait hal tersebut peneliti menguji pengaruh aktivitas penggunaan Instagram pada mahasiswa, pemberian kurikulum praktik kewirausahaan online, dan hasil belajar kewirausahaan online pada minat untuk berwirausaha secara online. Instagram dipilih karena merupakan trend saat ini, sementara literatur juga menyatakan adanya kepercayaan pada konsumen Instagram store (Che, Cheung, dan Thadani, 2017).

Prodi Manajemen Fakultas Ekonomi Universitas Sarjanawiyata Tamansiswa Yogyakarta melalui Mata Kuliah Manajemen Usaha Kecil dan Mikro memfasilitasi mahasiswa untuk memiliki unit usaha sebelum lulus kuliah dengan melaksanakan praktek pendirian dan pengelolaan online shop didukung pemagangan pada tempat usaha bisnis terkait. Kepemilikan unit usaha sebelum lulus kuliah menjadi tujuan karena unit usaha membutuhkan waktu untuk berkembang sehingga diharapkan ketika mahasiswa telah lulus kuliah, unit usaha yang dikelolanya telah berkembang dan menguntungkan. Cara ini juga diterapkan untuk berkompromi dengan masih adanya persepsi pada masyarakat bahwa mahasiswa yang belum bekerja menjadi pegawai negeri atau swasta dianggap belum bekerja meskipun telah memiliki penghasilan dari wirausaha. Mahasiswa dapat tetap memilih menjadi pegawai sambil mengelola online shop atau fokus menjadi wirausahawan online, yang mana kedua pilihan memiliki kesempatan untuk menjadi job maker. Penelitian ini ingin menguji dan mengetahui signifikansi pengaruh positif penggunaan instragram, pengalaman praktik kewirausahaan online, dan hasil belajar kewirausahaan online secara parsial terhadap minat berwirausaha online.

\section{Kajian Pustaka \\ Penggunaan Instagram}

Instagram digunakan untuk mendistribusikan informasi teks, audio, gambar, dan video yang dikreasikan oleh pemilik akun yang ditunjang oleh aplikasi pengolah gambar dengan membuat jaringan pertemanan secara virtual. Instagram menjadi sosial media yang membuka peluang untuk berbisnis bagi para penggunanya dengan melakukan komunikasi pemasaran dan berbagi informasi produk kepada follower, Instagram memudahkan konsumen melihat produk yang dijual dan dapat langsung memberi komentar dibawah foto yang diminati (Liang dan Turban, 2011). Instagram menonjol dalam pemasaran melalui gambar karena dalam pemasaran pemaparan gambar lebih menjadi fokus perhatian konsumen, hal ini membuat Instagram memiliki fungsi yang mendukung kelangsungan bisnis online. Pemanfaatan hastag juga digunakan luas di Instagram termasuk pada online shop lokal, hastag juga digunakan pengguna Instagram untuk mempermudah mencari produk yang ingin dibeli (Czarina dan Gutierrez, 2015).

Pengalaman Praktik Kewirausahaan Online 
Pengalaman praktik kewirausahaan menambah pengetahuan dan sebagai fasilitas pengusaha untuk beradaptasi dan mengatasi tantangan lingkungan berwirausaha (Cardon, Wincent, Singh, dan Drnovsek, 2009). Pengalaman Praktik berwirausaha juga menambah kreativitas seorang wirausahawan dalam inovasi produk dan penciptaan ide, pengalaman praktik berwirausaha juga menambah ketekunan dan pengalaman bagaimana memecahkan masalah ketika terjadi kegagalan dalam berwirausaha (Cardon et al., 2009).

\section{Hasil Belajar Kewirausahaan Online}

Pendidikan kewirausahaan merupakan proses perubahan dan pembentukan pengetahuan, keterampilan, sikap dan kemampuan seorang wirausahawan, melalui pelatihan, mentoring, ataupun pengalaman (Kuratko, 2005). Sebagian besar program tingkat universitas memberikan pendidikan kewirausahaan yang dimaksudkan untuk meningkatkan kompetensi dari materi yang ditargetkan, juga dirancang dan dilakukan untuk menjadikan mahasiswa memiliki keterampilan yang dibutuhkan, yang selanjutkan diharapkan dapat menumbuhkan jiwa wirausaha baru sebagai upaya menciptakan peluang usaha bagi diri sendiri maupun lingkungannya (Garavan dan Barra, 1994).

\section{Minat Berwirausaha Online}

Minat berwirausaha adalah keinginan, ketertarikan, serta kesediaan untuk bekerja keras atau berkemauan keras untuk berdikari atau berusaha memenuhi kebutuhan hidupnya tanpa merasa takut dengan risiko yang akan terjadi, serta senantiasa belajar dari kegagalan yang dialami (Carsrud dan Malin, 2011). Minat berwirausaha muncul karena diawali oleh suatu pengetahuan dan informasi mengenai wirausaha yang kemudian dilanjutkan pada suatu kegiatan wirausaha dengan ikut serta berpartisipasi untuk memperoleh pengalaman yang akhirnya memunculkan keinginan untuk melakukan kegiatan wirausaha tersebut (Carsrud dan Malin, 2011).

\section{Pengembangan Hipotesis}

Penggunaan Instagram telah meningkat sebagai media komunikasi pada mahasiswa. Media sosial menjadi cara pemasar mengikat konsumen dalam komunikasi personal dengan konten yang relevan. Adanya banyak penawaran produk melalui online shop, periklanan, dan peluang pasar diharapkan membuat mahasiswa sadar akan adanya peluang bisnis. Mahasiswa yang membangun jaringan pertemanan diharapkan menyadari peluang usaha dalam kegiatan sosialnya. Teknologi media sosial tidak hanya menyediakan platform baru bagi para wirausahawan untuk berinovasi tetapi juga mengangkat berbagai masalah baru bagi para peneliti e-commerce yang membutuhkan pengembangan teori baru (Liang dan Turban, 2011). Instagram akan memudahkan mahasiswa untuk mengakses informasi tentang dunia wirausaha secara luas, sebagai contoh mahasiswa dapat melihat seorang wirausaha yang sukses kemudian bisa dijadikan inspirasi untuk berwirausaha, atau menggunakan jaringan pertemanan sebagai pasar. Fernández-Pérez, et al. (2015) menyatakan terdapat hubungan positif jaringan sosial terhadap intensi kewirausahaan akademik. Seroka-Stolka dan Tomski (2015) menemukan jumlah warganegara asing sebagai anggota portal media sosial internet terkait dengan tingkat niat berwirausaha internasional. Penggunaan media sosial yang merupakan media jaringan sosial diharapkan dapat meningkatkan minat berwirausaha online mahasiswa.

$\mathrm{H1}$ : penggunaan Instagram berpengaruh positif signifikan terhadap minat berwirausaha online. 
Membentuk mahasiswa untuk menjadi wirausahawan dapat dilakukan dengan teori dan praktik. Mahasiswa perlu diajarkan bagaimana menjadi seorang wirausaha melalui kegiatan praktik berwirausaha, tanpa diadakannya praktik, mahasiswa tidak dapat langsung terjun ke dunia usaha karena mahasiswa belum berpengalaman dan memahami lingkungan (Kuckertz, 2010). Mahasiswa yang sudah memiliki pengalaman keuntungan usaha yang signifikan akan mengulangi perilakunya dan memperbaiki metodenya agar mendapatkan keuntungan yang lebih tinggi. Sumber daya manusia yang memiliki pengalaman akan dapat menjalankan usaha yang dijalankan dan akan meningkatkan kegiatan bisnis yang dijalani. Hasil penelitian menemukan pendidikan berpengaruh positif terhadap minat berwirausaha pada pelajar di China (Kaijun dan Sholihah, 2015).

$\mathrm{H} 2$ : pengalaman praktik berwirausaha berpengaruh positif signifikan terhadap minat berwirausaha online.

Literatur telah mengidentifikasi dua perspektif teoritis yang berpendapat bahwa hasil belajar berwirausaha berhubungan positif dengan minat berwirausaha online: (1) teori modal manusia (Becker, 1975) dan (2) selfefficacy kewirausahaan (Chen, 2010). Hasil belajar kewirausahaan merupakan keterampilan dan pengetahuan yang diperoleh individu melalui investasi selama menempuh pendidikan di perguruan tinggi, karena pendidikan kewirausahaan dapat menumbuhkan sikap dan minat mahasiswa untuk mendirikan peluang usaha baru (Liñan, 2008). Pendidikan kewirausahaan dikaitkan dengan self-efficacy kewirausahaan yang dapat meningkatkan minat berwirausaha online (Wilson, Kickul, dan Marlino, 2007; Zhao, Seibert, dan Hills, 2005).
H3: hasil belajar kewirausahaan online berpengaruh positif signifikan terhadap minat berwirausaha online.

\section{Metode Penelitian}

Penelitian ini bersifat kuantitatif, menggunakan data primer yang diperoleh dari jawaban responden atas kuesioner yang diberikan. Pertanyaan pengukuran semua variabel menggunakan 7 point skala Likert. Populasi dalam penelitian ini adalah Mahasiswa Prodi Manajemen Fakultas Ekonomi Universitas Sarjanawiyata Tamansiswa yang menempuh Mata Kuliah Manajemen Usaha Kecil dan Mikro. Mata Kuliah ini berisikan pembelajaran praktik kewirausahaan online yang berlangsung penuh selama satu semester. Mahasiswa diwajibkan membangun satu online shop di Instagram, dan juga diwajibkan membuat online shop di media lain sesuai keinginan mereka, antara lain Facebook, Line, BBM, OLX.co.id, Lazada.co.id, Bukalapak.com, Tokopedia.com, Kaskus.co.id, Shopee.co.id, dan lainnya. Teknik pengambilan sampel menggunakan saturation sampling dengan hasil sample size 84 mahasiswa.

Pengukuran penggunaan instagram menggunakan indikator dari Ting (2014) pengalaman praktik kewirausahaan dari Kaijun dan Sholihah (2015), prestasi belajar dari nilai mata kuliah Manajemen Usaha Kecil dan Mikro serta Indeks Prestasi Kumulatif, dan minat berwirausaha online dari Wang dan Lin (2016) serta Turan dan Kara (2018). Metode analisis data dilakukan menggunakan regresi linier berganda, pengujian hipotesis 1 sampai 3 menggunakan uji t. Pengaruh variabel bebas terhadap variabel terikat signifikan bila nilai t memiliki $p$ value (one tail)/ $2<$ 0,05 . Adjusted $R$ square menunjukkan kemampuan variabel bebas dalam menjelaskan varians variabel terikat.

$\mathbf{M B O}=\mathbf{a}+\mathbf{b} 1 \mathrm{PI}+\mathbf{b} 2 \mathbf{P P}+\mathbf{b 3 H B}$ 
Keterangan:

A : konstanta;

B : koefisien;

MBO: Minat Berwirausaha Online;
PI : Penggunaan Instagram;

PP :Pengalaman Praktik Kewirausahaan Online;

HB : Hasil Belajar Kewirausahaan Online.

Tabel 1 Karakteristik Responden

\begin{tabular}{|c|c|c|c|}
\hline & Keterangan & Frekuensi & Persen \\
\hline Jender & Laki-laki & 35 & 41,7 \\
\hline Jender & Perempuan & 49 & 58,3 \\
\hline & Mahasiswa & 69 & 82,1 \\
\hline Pelarian & PNS/TNI/Polri/Pegawai BUMN & 1 & 1,2 \\
\hline Рекеrjaan & Pegawai Swasta & 13 & 15,5 \\
\hline & Lainnya & 1 & 1,2 \\
\hline & Kurang dari Rp 1.000.000,00 & 49 & 58,3 \\
\hline & Rp 1.000.000,00 - Rp 3.000.000,00 & 30 & 35,7 \\
\hline Penghasilan & Diatas Rp 3.000.000,00 - Rp 5.000.000,00 & 4 & 4,8 \\
\hline & Diatas Rp 5.000.000,00 & 1 & 1,2 \\
\hline & Kurang dari 3 bulan & 27 & 32,1 \\
\hline I amo & 3 bulan -6 bulan & 48 & 57,1 \\
\hline Lama usana & Diatas 6 bulan -1 tahun & 6 & 7,1 \\
\hline & Diatas 1 tahun - 3 tahun & 3 & 3,6 \\
\hline & Sudah mati & 7 & 8,3 \\
\hline & Masih berjalan tapi rugi & 12 & 14,3 \\
\hline & Kadang rugi kadang untung perbulannya & 38 & 45,2 \\
\hline oline shop & $\begin{array}{l}\text { Selalu untung namun dibawah } \\
\text { Rp 2.000.000,00 perbulan }\end{array}$ & 26 & 31,0 \\
\hline & $\begin{array}{l}\text { Selalu untung diatas Rp 2.000.000,00 } \\
\text { perbulan }\end{array}$ & 1 & 1,2 \\
\hline & Jumlah & 84 & 100,00 \\
\hline & Mean & 23,05 & \\
\hline Usia & Median; Mode & $21 ; 21$ & \\
\hline & Min; Max & $19 ; 56$ & \\
\hline
\end{tabular}

Sumber: Data diolah, 2018.

\section{Hasil Penelitian}

\section{Karakteristik Responden}

Karakteristik responden (Tabel 1) menampilkan jumlah perempuan $(58,3 \%)$ lebih banyak dari laki-laki $(41,7 \%)$, responden memiliki rata-rata usia 23,05 tahun, dan sebanyak 17,9\% mahasiswa telah bekerja. Hanya terdapat $10,7 \%$ mahasiswa yang telah menjalankan online shop diatas 6 bulan atau telah mempraktikkan online shop sebelum Mata Kuliah Manajemen Usaha Kecil dan Mikro diberikan, namun sudah terdapat $32,2 \%$ mahasiswa berani menyatakan selalu untung perbulannya.

\section{Uji Kualitas Data}

Pengujian validitas variabel penggunaan Instagram menghasilkan nilai $\mathrm{r}$ hitung diantara 0,367 sampai 0,629 ; variabel pengalaman praktik kewirausahaan diantara 0,784 sampai 
0,938; variabel hasil belajar 0,306 sampai 0,628 , variabel minat berwirausaha online diantara 0,744 sampai 0,907 , artinya indikator berada diatas $\mathrm{r}$ tabel $0,1807(\mathrm{~N}=84 ; \alpha=0,05$ (one tail)) atau valid. Indikator yang valid menunjukkan alat ukur sudah mengukur apa yang ingin diukur. Pengujian reliabilitas variabel penggunaan Instagram menghasilkan Cronbach's Alpha Based on Standardized Items 0,878 , variabel pengalaman praktik kewirausahaan 0,988 , variabel hasil belajar praktik kewirausahaan 0,708, dan minat berwirausaha online 0,983 , yang semuanya diatas 0,6 atau semua variabel sudah reliabel. Hasil pengukuran yang reliabel menunjukkan bahwa jawaban seseorang terhadap pernyataan adalah konsisten dari waktu ke waktu.

\section{Asumsi Klasik}

Hasil verifikasi multikolonieritas (Tabel 2) menunjukkan nilai tolerance berada diatas 0,10 , atau tidak ada korelasi antara variabel bebas yang nilainya lebih dari $95 \%$. Nilai VIF tidak ada yang melebihi 10 atau tidak ada mulitikolonieritas antar variabel bebas dalam model regresi. Hasil coefficient correlations (Tabel 3) menunjukkan bahwa korelasi terbesar (-) 0,511 atau
$51,1 \%$ antara variabel praktik kewirausahaan online dengan penggunaan Instagram masih di bawah 95\%, artinya tidak terjadi multikolonieritas yang serius.

Pengujian heteroskedastisitas menggunakan spearman-rho test (Tabel 2) menghasilkan nilai probabilitas dari correlation coefficient pada semua variabel bebas terhadap unstadardized residual $<0,05$ atau tidak signifikan. Grafik scatterplot (Gambar 1) memperlihatkan titik-titik menyebar secara acak serta tersebar baik di atas maupun di bawah angka 0 pada sumbu Y, artinya tidak terjadi heteroskedastisitas pada model regresi. Hasil grafik scatterplot dan spearmanrho saling konsisten menyatakan homoskedastisitas pada model regresi. Pengujian normalitas dengan grafik normal probability plot (Gambar 1) menghasilkan pola sebaran titik-titik berada disekitar garis diagonal dan mengikuti garis diagonal yang diartikan pola distribusi normal. Nilai Kolmogorov-Smirnov $Z \quad 0,977$ dengan nilai asymp.sig (t-tailed) 0,295 > 0,05 yang artinya data residual berdistribusi normal. Hasil grafik normal probability plot dan Kolmogorov-Smirnov test konsisten menyatakan model regresi memenuhi asumsi normalitas.

Tabel 2 Hasil Asumsi Klasik

\begin{tabular}{|c|c|c|c|c|c|c|c|c|c|}
\hline \multicolumn{2}{|c|}{ Variabel } & \multicolumn{2}{|c|}{$\begin{array}{l}\text { Multikolonier } \\
\text { itas }\end{array}$} & \multicolumn{2}{|c|}{ Variabel } & \multicolumn{2}{|c|}{$\begin{array}{c}\text { Heteroskedastisitas } \\
\text { (Spearman- Rho) }\end{array}$} & \multicolumn{2}{|c|}{$\begin{array}{c}\text { Normalitas } \\
\text { (Kolmogorov- } \\
\text { Smirnov Test) }\end{array}$} \\
\hline Bebas & Terikat & $\begin{array}{l}\text { Tolera } \\
\text { nce }\end{array}$ & $V I F$ & Bebas & Terikat & $\begin{array}{c}\text { Correlation } \\
\text { coeff. }\end{array}$ & $\begin{array}{l}\text { Sig. (1- } \\
\text { tailed) }\end{array}$ & $\mathbf{K S}-\mathbf{Z}$ & Sign. \\
\hline PI & \multirow{3}{*}{$\mathrm{MBO}$} & 0,580 & 1,724 & $\mathrm{PI}$ & \multirow{3}{*}{$\begin{array}{l}\text { Unstand. } \\
\text { Residual }\end{array}$} & 0,022 & 0,420 & \multirow{3}{*}{0,977} & \multirow{3}{*}{0,295} \\
\hline $\mathrm{PP}$ & & 0,644 & 1,552 & PP & & 0,145 & 0,094 & & \\
\hline HB & & 0,774 & 1,292 & HB & & 0,019 & 0,433 & & \\
\hline
\end{tabular}

Sumber: Data diolah, 2018. 
Tabel 3 Coefficient Correlations

\begin{tabular}{|c|c|c|c|c|c|}
\hline \multicolumn{6}{|c|}{ Coefficient Correlations ${ }^{a}$} \\
\hline & & Model & $\begin{array}{c}\text { Hasil Belajar } \\
\text { Praktik } \\
\text { Kewirausahaan } \\
\text { Online }\end{array}$ & $\begin{array}{c}\text { Praktik } \\
\text { Kewirausahaan } \\
\text { Online }\end{array}$ & $\begin{array}{l}\text { Penggunaan } \\
\text { Instagram }\end{array}$ \\
\hline \multirow[t]{6}{*}{1} & Correlations & $\begin{array}{l}\text { Hasil Belajar Praktik Kewirausahaan } \\
\text { Online }\end{array}$ & 1.000 & -.118 & -.335 \\
\hline & & Praktik Kewirausahaan Online & -.118 & 1.000 & -.511 \\
\hline & & Penggunaan Instagram & -.335 & -.511 & 1.000 \\
\hline & Covariances & $\begin{array}{l}\text { Hasil Belajar Praktik Kewirausahaan } \\
\text { Online }\end{array}$ & .097 & -.002 & -.011 \\
\hline & & Praktik Kewirausahaan Online & -.002 & .003 & -.003 \\
\hline & & Penggunaan Instagram & -.011 & -.003 & .011 \\
\hline
\end{tabular}

a. Dependent Variable: Minat Berwirausaha Online

Sumber: Data diolah, 2018.

Scatterplot

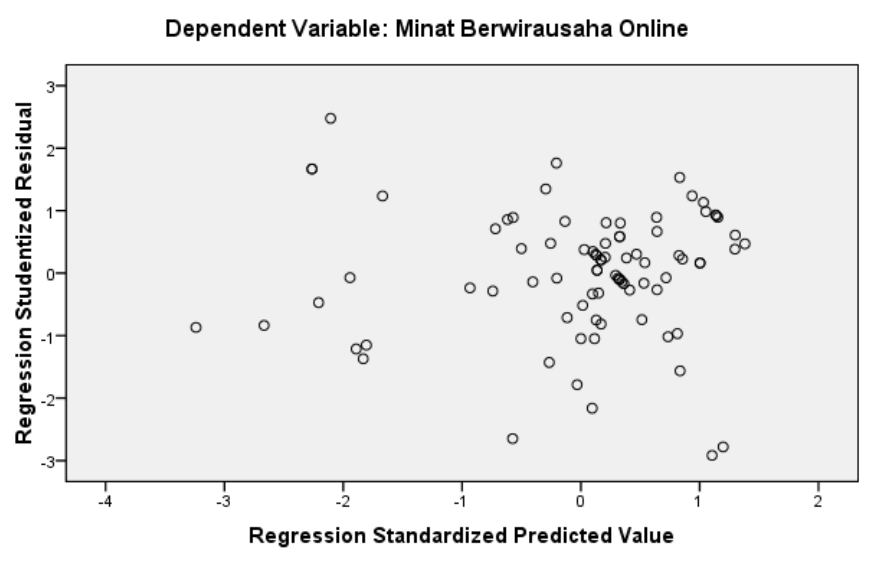

Dependent Variable: Minat Berwirausaha Online

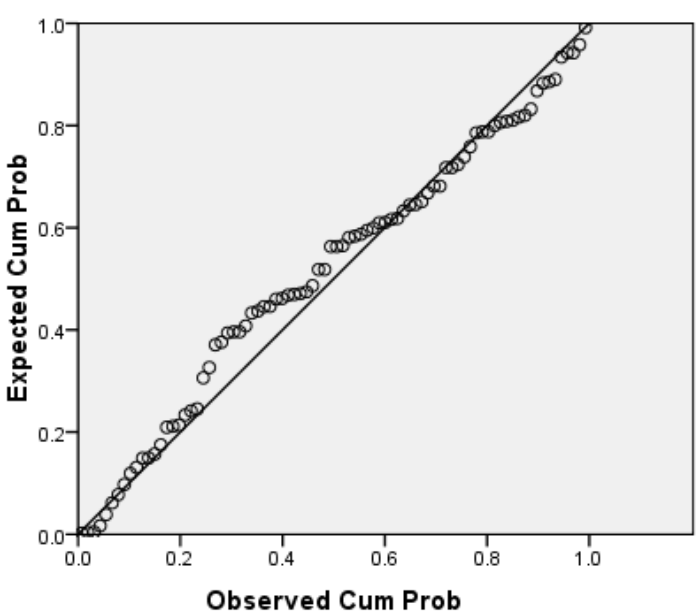

Sumber: Data diolah, 2018.

\section{Koefisien Determinasi}

Tampak bahwa kemampuan variabel penggunaan Instagram, pengalaman praktik kewirausahaan online, dan hasil belajar praktik kewirausahaan online dalam menjelaskan varians variabel minat berwirausaha online adalah sebesar 79,0\% (Tabel 4). Terlepas dari $21 \%$ varians variabel minat berwirausaha online yang belum 
mampu dijelaskan namun adjusted $R$ square $>50 \%$ menunjukkan variabel penggunaan Instagram, pengalaman praktik kewirausahaan online, dan hasil belajar praktik kewirausahaan online mampu menjadi variabel penjelas yang besar.

Tabel 4 Koefisien Determinasi

\begin{tabular}{|c|c|c|c|c|}
\hline \multicolumn{5}{|c|}{ Model Summary ${ }^{b}$} \\
\hline Model & $R$ & $R$ Square & $\begin{array}{l}\text { Adjusted } R \\
\text { Square }\end{array}$ & $\begin{array}{l}\text { Std. Error of the } \\
\text { Estimate }\end{array}$ \\
\hline 1 & $.893^{a}$ & .798 & .790 & 8.878 \\
\hline \multicolumn{5}{|c|}{$\begin{array}{l}\text { a. Predictors: (Constant), Hasil Belajar Praktik Kewirausahaan } \\
\text { Online, Praktik Kewirausahaan Online, Penggunaan Instagram }\end{array}$} \\
\hline \multicolumn{5}{|c|}{ b. Dependent Variable: Minat Berwirausaha Online } \\
\hline
\end{tabular}

\section{Pengujian Hipotesis}

Hasil uji t (Tabel 5) dari regresi linier berganda menunjukkan hipotesis pertama yang menyatakan penggunaan Instagram berpengaruh positif signifikan terhadap minat berwirausaha online ditolak, yang dibuktikan dengan nilai probabilitas $0,777 / 2=0,3885>0,05$ atau tidak signifikan. Hipotesis kedua yang menyatakan pengalaman praktik kewirausahaan online berpengaruh positif signifikan terhadap minat berwirausaha online diterima, yang dibuktikan dengan nilai probabilitas $0,000 / 2=0,000<0,05$. Hipotesis ketiga yang menyatakan hasil belajar praktik kewirausahaan online berpengaruh positif signifikan terhadap minat berwirausaha online diterima yang dibuktikan dengan nilai probabilitas $0,014 / 2=0,07<0,05$. Nilai standardized coefficients beta terbesar adalah praktik kewirausahaan online $(0,820)$, diikuti hasil belajar praktik kewirausahaan online $(0,144)$ (Gambar 2).

\section{Tabel 5 Uji t}

\begin{tabular}{|c|c|c|c|c|c|c|}
\hline \multirow{2}{*}{\multicolumn{2}{|c|}{ Model }} & \multicolumn{2}{|c|}{$\begin{array}{c}\text { Unstandardized } \\
\text { Coefficients }\end{array}$} & \multirow{2}{*}{$\begin{array}{c}\begin{array}{c}\text { Standardized } \\
\text { Coefficients }\end{array} \\
\text { Beta }\end{array}$} & \multirow[b]{2}{*}{$t$} & \multirow[b]{2}{*}{ Sig. } \\
\hline & & $B$ & Std. Error & & & \\
\hline \multirow[t]{4}{*}{1} & (Constant) & 21.282 & 7.338 & & 2.900 & .005 \\
\hline & Penggunaan Instagram & .029 & .102 & .019 & .284 & .777 \\
\hline & $\begin{array}{l}\text { Praktik Kewirausahaan } \\
\text { Online }\end{array}$ & .728 & .056 & .820 & 13.094 & .000 \\
\hline & $\begin{array}{l}\text { Hasil Belajar Praktik } \\
\text { Kewirausahaan Online }\end{array}$ & .784 & .312 & .144 & 2.512 & .014 \\
\hline
\end{tabular}

Sumber: Data diolah, 2018.

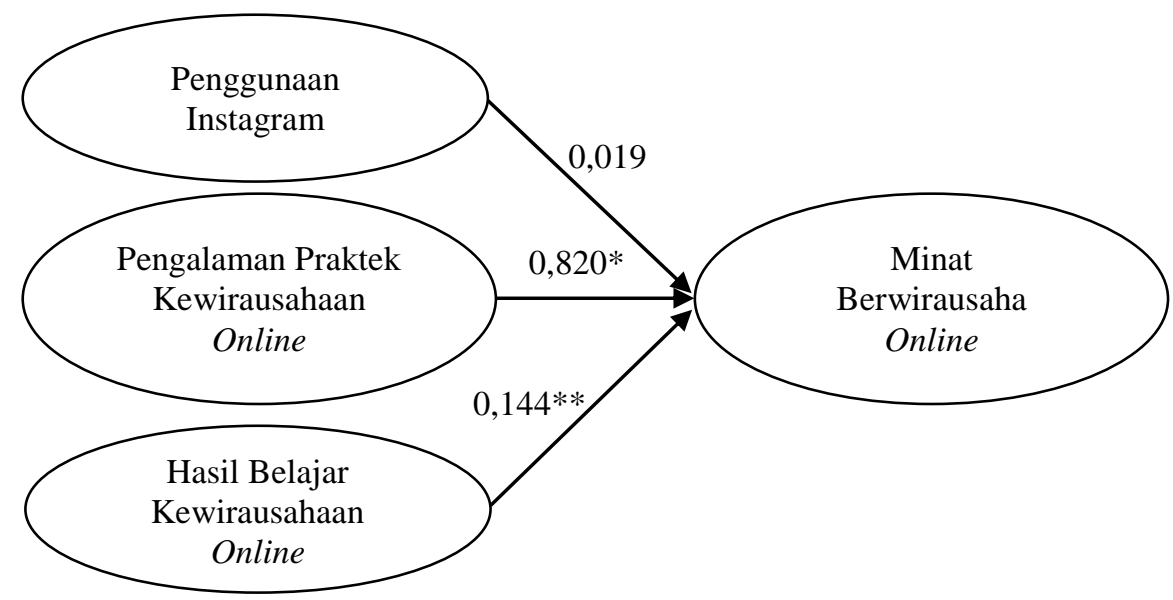


Ket. * $p<0,01 ; * *$ sig $<0,05$

\section{Gambar 2 Model Penelitian}

Pembahasan

Uji hipotesis pertama menunjukkan Persepsi penggunaan Instagram tidak berpengaruh secara signifikan terhadap minat berwirausaha online, penelitian ini tidak mendukung peneliti terdahulu yang menyatakan bahwa teknologi media sosial dapat menyediakan platform baru bagi para wirausahawan untuk berinovasi dan menambah minat berwirausaha (Liang dan Turban, 2011). Perbedaan hasil penelitian ini menunjukkan bahwa penggunaan Instagram oleh mahasiswa tidak dengan sendirinya menciptakan minat berwirausaha. Penggunaan Instagram untuk saat ini bukan sebagai media inovatif berinteraksi secara online terkait kewirausahaan, tetapi hanya sebagai media mengekspresikan dirinya dengan memanfaatkan jaringan internet melalui perangkat smartphone atau komputer sebagai media hiburan dan mengisi waktu luangnya. Adebayo (2015) juga menemukan hubungan tidak signifikan antara jaringan sosial online dan kemauan siswa untuk memulai bisnis, studi ini merekomendasikan bahwa siswa perlu mengubah orientasi mereka untuk menggunakan jaringan sosial online sebagai platform ide bisnis, identifikasi peluang dan jaringan bisnis.

Uji Hipotesis kedua menunjukkan bahwa pengalaman praktik berwirausaha online berpengaruh positif signifikan terhadap minat berwirausaha online. Penelitian ini mendapatkan hasil yang sama dengan penelitian terdahulu (Kuckertz, 2010) yang menyatakan untuk menjadi seorang wirausaha dibutuhkan sumber daya manusia yang berpengalaman, sumber daya yang memiliki pengalaman akan mampu untuk membaca peluang dalam menjalankan usaha yang dijalankan dan akan meningkatkan kegiatan bisnis yang dijalani. Pada pendidikan di perguruan tinggi, mahasiswa perlu diajarkan dan dilatih bagaimana menjadi seorang wirausaha melalui kegiatan praktik berwirausaha online, tanpa diadakannya praktik berwirausaha online mahasiswa tidak dapat langsung terjun ke dunia usaha karena mahasiswa belum mengetahui situasi dan kondisi lingkungan. Semakin mahasiswa mendapatkan praktek kewirausahaan secara nyata, semakin mahasiswa paham cara membuka online shop, berinteraksi dengan pelanggan secara online, melakukan pengiriman, dan melayani transaksi online. Semakin bertambah pengalaman yang didapat melalui kegiatan praktek berakibat semakin tinggi minat untuk berwirausaha online. Pengalaman praktik berwirausaha menambah pengetahuan dan sebagai fasilitas pengusaha untuk beradaptasi dan mengatasi tantangan lingkungan berwirausaha (Cardon et al. 2009).

Uji Hipotesis ketiga menunjukkan bahwa hasil belajar praktik berwirausaha online berpengaruh positif signifikan terhadap minat berwirausaha online. Temuan ini konsisten dengan penelitian terdahulu, bahwa hasil belajar kewirausahaan merupakan cerminan keterampilan dan pengetahuan yang diperoleh mahasiswa melalui investasi selama menempuh pendidikan di perguruan tinggi, karena pendidikan kewirausahaan dapat menumbuhkan sikap dan minat mahasiswa untuk mendirikan peluang usaha baru (Liñan, 
2008). Pendidikan kewirausahaan dikaitkan dengan self-efficacy kewirausahaan, yang dapat meningkatkan minat berwirausaha online (Wilson, Kickul, dan Marlino, 2007; Zhao, Seibert, dan Hills, 2005). Oleh karena itu, mahasiswa dengan hasil belajar kewirausahaan online yang baik akan terdorong untuk meningkatkan minat berwirausaha online.

\section{Kesimpulan dan Saran}

Berdasarkan hasil pengujian dapat disimpulkan bahwa kegiatan rutin mahasiswa menggunakan Instagram tidak dengan sendirinya menciptakan minat berwirausaha online. Penentu minat berwirausaha online mahasiswa adalah pengalaman praktik berwirausaha online dan hasil belajar berwirausaha online. Hal tersebut berimplikasi bahwa mahasiswa perlu diajarkan bagaimana menjadi seorang wirausaha melalui kegiatan praktik berwirausaha online, tanpa diadakannya praktik, mahasiswa tidak dapat langsung terjun ke dunia usaha karena mahasiswa belum mengetahui situasi dan kondisi lingkungan. Lebih lanjut, capaian prestasi akademik merupakan cerminan kompetensi pengetahuan dan keterampilan kewirausahaan online. Maka mendorong mahasiswa memperoleh prestasi akademik yang baik berarti meningkatkan pengetahuan kewirausahaan yang akan berdampak meningkatkan minat berwirausaha online. Penelitian kedepan perlu mempertimbangkan variabel lain yang dapat meningkatkan koefisien determinasi minat berwirausaha online. Bagaimana mengaitkan penggunaan media sosial terhadap kegiatan kewirausahaan melalui variabel penjelas lain perlu digali lebih mendalam, mengingat media sosial telah menjadi kebutuhan bagi anak muda saat ini.

\section{Daftar Pustaka}

Adebayo. 2015. Impact of Social Media on Students Entrepreneurial Orientation: A Study of Selected Institutions in Nigeria. Journal of Advance Research in Business, Management and Accounting, 1(10): 12-25.

Azali, Kathleen. 2017. "Indonesia's Divided Digital Economy." Yusof Ishak Institute. 2017(70), 1-12.

Becker, G. S. 1975. Human capital (2nd ed.). Chicago: University of Chicago Press.

Cardon, Melissa S., Joakim Wincent, Jagdip Singh, dan Mateja Drnovsek. 2009. "The Nature And Experience of Entrepreneurial Passion." Academy of Management Review, 34(3), 511-532.

Carsrud, Alan dan Malin Brännback. 2011. "Entrepreneurial Motivations: What Do We Still Need to Know?" Journal of Small Business Management, 49(1), 9-26.

Che, Jasmine W. S., Christy M. K. Cheung, dan Dimple R. Thadani. 2017. "Consumer Purchase Decision in Instagram Stores: The Role of Consumer Trust." Proceedings of the 50th Hawaii International Conference on System Sciences.

Chen, Y. 2010. "Does Entrepreneurship Education Matter To Students' Entrepreneurial Intention? A Chinese Perspective. Paper Presented at Second International Conference on Information Science and Engineering." China, December 4-6. 
Czarina, Waga dan Nichole Gutierrez. March 2-4, 2015. "The Structures of Hashtags Used by InstagramBased Online Shops." Presented at the DLSU Research Congress 2015 De La Salle University, Manila, Philippines.

Fernández-Pérez, V., Alonso-Galicia, P.E., Fuentes-Fuentes, M. d. M., \& Rodriguez-Ariza, L. 2014. "Business social networks and academics' entrepreneurial intentions." Industrial Management \& Data Systems, 114(2), 292-320. Doi:10.1108/IMDS02-2013-0076.

Garavan, Thomas N. \& Barra O’Cinneide. 1994.

"Entrepreneurship Education and Training Programmes: A Review and Evaluation-Part 1." Journal of European Industrial Training, 18(8), 3-12.

Google Temasek. 2016. "E-conomy SEA: Unlocking the \$200 Billion Digital Opportunity in Southeast Asia." https://www.thinkwithgoogle.com/intl len-apac/trends-and-insights/economy-sea-unlocking-200b-digitalopportunity/. Diakses 15 Oktober 2018.

Kaijun, Yang dan Puput Ichwatus Sholihah. 2015. "Comparative Study Of The Indonesia and Chinese Educative Systems Concerning The Dominant Incentives to Entrepreneurial Spirit (Desire for A New Venturing) of Business School Students." Journal of Innovation and Entrepreneurship, 4(1): 1-16. Doi 10.1186/s13731-014-0014-0.

Kuckertz, Andreas. 2010. "The Influence of Sustainability Orientation on Entrepreneurial Intentions-Investigating The Role of Business Experience." Journal of Business Venturing, 25(2010), 524-539.
Kuratko, Donald F. 2005. "The Emergence of Entrepreneurship Education: Development, Trends, and Challenges." Journal of Behavioural Economics, Finance, Entrepreneurship, Accounting and Transport, 2(3), 63-69.

Lee, MinHwa, JinHyo Joseph Yun, Andreas Pyka, DongKyu Won, Fumio Kodama, Fumio Kodama, Giovanni Schiuma, HangSik Park, Jeonghwan Jeon, KyungBae Park, KwangHo Jung, Min-Ren Yan, SamYoul Lee, dan Xiaofei Zhao. 2018. "How to Respond to the Fourth Industrial Revolution, or the Second Information Technology Revolution? Dynamic New Combinations between Technology, Market, and Society through Open Innovation." Journal of Open Innovation: Technology, Market and Complexity, 4(21); 1-24.

Lee, S.-H., \& J. E. Workman. 2015. "Determinants of Brand Loyalty: Self-Construal, Self-Expressive Brands, and Brand Attachment." International Journal of Fashion Design, Technology and Education, 8(1), 12-20.

Liang, Ting-Peng dan Efraim Turban. 2011. "Introduction to the Special Issue Social Commerce: A Research Framework for Social Commerce." International Journal of Electronic Commerce / Winter 2011-12, 16(2), 5-13.

Liñán, F. 2008. "Skill dan Value Perceptions: How do They Affect Entrepreneurial Intentions." International Entrepreneurship and Management Journal, 4(3), 257272.

Millman, C., W. C. Wong, Z. Li, dan H. Matlay. 2009. "Educating Students for E-entrepreneurship in the UK, the USA and China." Industry and Higher Education, 23(3), 243-252. 
Seroka-Stolka, Oksana dan Piotr Tomski. 2015. "Internet Social Media and International Entrepreneurial Intentions," WEI International Academic Conference Proceedings Vienna, Austria.

Ting Ting, Cheung. 2014. "A Study of Motives, Usage, Self-presentation and Number of Followers on Instagram." Discovery - SS Student E-Journal. 3(2014): 1-35.

Turan, Mehmet dan Kara, Ali. 2018. Online Social Media Usage Behavior of Entrepreneurs in an Emerging Market: Reasons, Expected Benefit and Intentions," Journal of Reseach in Marketing and Entrepreneurship. https:doi.org/10.1108/JRME-092016-0034.
Wang, Yu-Min dan Yi-Shuan Lin.2016. Determinants of Internet Entrepreneurship Intentions among Business School Students. International Journal of Information and Education Technology, 6(10):754-758.

Wilson, Fiona, Jill Kickul, dan Deborah Marlino. 2007. "Gender, Entrepreneurial Self-Efficacy, and Entrepreneurial Career Intentions: Implications For Entrepreneurship Education." Entrepreneurship Theory and Practice, 31(3), 387-406.

Zhao, Hao, Scoot E. Seibert, dan Gerald E. Hills. 2005. "The Mediating Role of Self-Efficacy in the Development of Entrepreneurial Intentions." Journal of Applied Psychology, 90(6), 12651272. 